ACTA AGROBOTANICA

Vol. 59, z. 12006

s. 6169

\title{
Ecophysiological aspects of nectar reabsorption
}

\section{MAŁGORZATA STPICZYŃSKA ${ }^{1}$, MASSIMO NEPI ${ }^{2}$}

${ }^{1}$ Department of Botany Agricultural University of Lublin, Akademicka 15, 20950 Lublin

${ }^{2}$ Department of Environmental Biology, University of Siena, via P.A. Mattioli 4, 53100 Siena

(Received: 16.11.2005)

\section{S u m m ary}

A number of approaches, both direct and indirect, have shown that nectar is reabsorbed by numerous plant species, irrespective of the age or sex of the flower. Furthermore, reabsorption occurs regardless of whether or not the flower has been pollinated. Reabsorption helps to maintain concentration of nectar and their viscosity and thereby encourages continued visits by pollinators. Conversely, the capacity to vary concentration of nectar sugars may confer evolutionary advantage by encouraging visits by more than one kind of pollinator and this is particularly important in regions where there is a paucity of pollinators. A further important role of nectar reabsorption is the maintenance of the energy equilibrium of the plant. A number of studies have shown that nectar production involves considerable energy expenditure requiring as much as $37 \%$ of the plant's daily production of energy by photosynthesis. The increased metabolic costs incurred by the plant during nectar production and secretion can reduce its growth and reproduction during the following season. Reabsorption of nectar that has not been collected by pollinators enables the plant to conserve at least some of the energy reserved for the secretion of nectar. Sugars reabsorbed from nectar can be re-used for the development of fruit and ovules processes which demand large quantities of sugar. Despite convincing evidence for the reabsorption of nectar, few detailed studies have addressed the transport and incorporation of reabsorbed sugars. One of the questions that remain to be answered is 'What is the cellular basis for nectar reabsorption by the nectary?'. 


\section{INTRODUCTION}

In the majority of plants, nectar composition is never static. Indeed, it changes throughout the course of anthesis by a combination of various processes; nectar secretion, cessation of the secretion and the reabsorption of the nectar. Ever since B o n $\mathrm{n}$ i e r (1878) suggested that flowers of Platanthera reabsorb nectar, many studies have been published that demonstrate this process, either directly or indirectly. The reabsorption of nectar is not the exceptional floral feature. It has been reported for many plant species and occurs regardless of the age or sex of the flower and irrespective of whether or not pollination has taken place. Neither does it depend upon the structure of the nectary nor the manner in which the nectar is secreted, whether it be via modified stomata or unicellular, glandular hairs. B u rqú e z and C or bet (1991) studied the reabsorption of nectar in Brassica napus by measuring net solute loss in flowers that had not been visited by pollinators. Likewise, Masie row ska and S t pi c zy ńska (2005) have confirmed that nectar is reabsorbed in other species of Brassicaceae. The reabsorption of uncollected nectar has also been observed to occur in Cucurbita pepo (N e p i et al., 1996a; 1996b; 2001; A s h w or th and Ga le t to, 2002), Eucalyptus (D a v is , 1997), as well as Silene and Saponaria (W it t et al., 1999), Mystacidium venosum ( $\mathrm{L} \mathrm{u} \mathrm{y} \mathrm{t} \mathrm{and} \mathrm{J} \mathrm{o} \mathrm{h} \mathrm{n} \mathrm{s} \mathrm{o} \mathrm{n,} \mathrm{2001;} \mathrm{2002)} \mathrm{and} \mathrm{Aloe} \mathrm{casta-}$ $n e a(\mathrm{Ni} \mathrm{c} \mathrm{o} l \mathrm{~s}$ o $\mathrm{n}$ and $\mathrm{Ne} \mathrm{p} \mathrm{i,2005).} \mathrm{The} \mathrm{reabsorption} \mathrm{of} \mathrm{nectar} \mathrm{also} \mathrm{occurs} \mathrm{in} \mathrm{Carum}$ carvi, following both the male and female flower stages (Lange nberger and D a v i s, 2002), or towards the end of anthesis as in Combretum fruticosum (B e r $\mathrm{n}$ a rde 11 o et al., 1994), Ligaria cuneifolia (R i v e ir a et al., 1996), Mandevilla pentlandiana (Torres and Galetto, 1998), Platanthera chlorantha (S t p i c z y ńs k a, 2003 a, b; 2004) and Sophora fernandeziana (B e rnardello et al., 2004). For many species, there is convincing evidence that the processes of nectar reabsorption and nectar secretion occur simultaneously and that, on occasion, the former continues even when nectar secretion has ceased (C o r b e t, 2003).

Microautoradiography is currently used to study the reabsorption of nectar, however formerly, this technique was employed to investigate the process of nectar secretion (Fahn and Rachmilewitz, 1975; Heinrich, 1975; S awidis et al., 1989). By means of autoradiography, Pe d e r s e n et al. (1958) have demonstrated the reabsorption of nectar and the translocation of sugar at the macroscopic level in alfalfa. Hitherto, detailed microautoradiographical studies have been confined to the study of nectar reabsorption in Platanthera chlorantha and Cucurbita pepo two species showing quite different types of nectary and differing both in the dynamics and manner of nectar secretion (S t p i c z y ń s k a , 2003 a, b; S t p i c z y ń s k a , 2004; Stpiczyńska and Nepi, 2005; Nepi and Stpiczyńska, unpublished).

\section{Nectar reabsorption and plant-pollinator interactions}

The reabsorption of nectar sugar fulfils an important ecological role. It enables the maintenance of constant nectar sugar concentrations and nectar viscosity even when these increase due to the evaporation of water. Since the composition and sugar 
concentration of nectar are related to the type of pollinator (B a ker and B a ker, 1983), thus the reabsorption of sugars reduces the viscosity of the nectar and facilitates nectar probing as in Penstemon gentianoides ( $\mathrm{Cruden}$ at al., 1983) and birdpollinated flowers (Baker, 1975; Nicolson, 1995; Nicols on and $\mathrm{Nepi}$, 2005). This homeostatic mechanism may be an important factor in ensuring that the most effective pollinators continue to visit the flower. Equally noteworthy is the fact that water and the other constituents of nectar are reabsorbed to the same degree ( $\mathrm{N} \mathrm{e} \mathrm{p} \mathrm{i} \mathrm{at} \mathrm{al,} \mathrm{2001).} \mathrm{Conversely,} \mathrm{the} \mathrm{capacity} \mathrm{to} \mathrm{vary} \mathrm{sugar} \mathrm{concentration} \mathrm{may} \mathrm{be} \mathrm{an}$ adaptation to ensure that a greater variety of pollinators visit the flower, as in the case of Catalpa speciosa ( $\mathrm{Cr}$ u d e $\mathrm{n}$ et al., 1983). Moreover, if a pollinator fails to remove nectar, nectar reabsorption may discourage foraging by nectar thieves. In addition, the reabsorption of nectar reduces the damage caused during visits of the flowers that have already been pollinated (B u r qú e z and C o r b e t, 1991). In Mystacidium venosum, nectar is reabsorbed at night when pollinator activity is at its lowest ( $\mathrm{L} \mathrm{u} \mathrm{y} \mathrm{t}$ and J o h n s o n, 2001). Wit t et al. (1999) demonstrated that nectar reabsorption in Saponaria and Silene occurs late at night when the activity of nocturnal insects is decreased. Furthermore, dried nectar from the previous night is prevented from mixing with freshly secreted nectar. This is advantageous since mixing causes nectar to become viscous and it is possible that insects would tend to avoid visiting older flowers (Witt et al., 1999).

\section{Nectar reabsorption as an energy-saving strategy}

Another function of nectar reabsorption is the maintenance of the energy balance of the plant. Nectar production requires considerable expenditure of energy. In Asclepias syriaca, nectar production may use up to $37 \%$ of the energy produced by photosynthesis (S o u thwick, 1984). Koopowitz and Marchant (1998) estimated for Aerangis verdicki that the average amount of energy used per plant for nectar production during a single season was $684.2 \mathrm{~J}$. It is worthy to note that the removal of nectar from the flowers increased its net nectar production, as in Blandfordia nobilis (P y k e, 1991). Such increased nectar production can result in a reduction in plant growth and diminished reproductive capacity during the following season. Therefore, energy conservation is the main purpose for reabsorbing and recycling nectar sugars not collected by pollinators. However, reabsorption of nectar, like its secretion, involves the expenditure of energy and consequently, the former process is worthwhile only when there is an overall net gain in energy.

It has recently been proposed and/or demonstrated that this energy-conserving strategy operates in a number of species (B u rqú e z and C or b e t, 1991; K o o p o witz and Marchant, 1998; Luyt and Johnson, 2002; Stpiczyńska, 2004). For example, in Cucurbita pepo and Platanthera chlorantha, all unconsumed nectar is reclaimed, thus, maximising the recovery of energy invested in nectar production (Nepi and Stpiczyńska, unpublished). 


\section{Sugar reabsorption in flowers of different sex and at various sexual stages}

Nepi and co-workers (Nepi et al., 1996 b, 2001; S t p i c z y ńsk a and Ne pi 2005) have shown for Cucurbita pepo that both male and female flowers reabsorb unconsumed nectar. Reabsorbed sucrose labelled with ${ }^{14} \mathrm{C}$, although present in the floral nectary tissue of both sexes, differed in its distribution. In the nectary of male flowers, sucrose from reabsorbed nectar was concentrated predominantly in superficial parts of the nectary, largely, just below the epidermis. Reabsorbed sucrose was almost absent from the vascular bundles of the pedicel of the male flower. Conversely, in the female flowers, it was absent from the outermost nectary tissue but present in the deeper-located cells. It indicates that, in female flowers, the reabsorbed nectar is more mobile and reabsorbed sugar remained longer in the nectaries of male than those of female flowers. As has previously been demonstrated, the nectaries of female flowers have higher reabsorption rates and they selectively reabsorb sucrose at a greater rate than they reabsorb water ( $\mathrm{Ne} \mathrm{p} \mathrm{i} \mathrm{et} \mathrm{al.,} \mathrm{2001).}$

The reabsorption of nectar by the protandrous florets of Carum carvi, following both male and female stages was studied by Lange nberger and Davis (2002). The study showed that sugars in the nectar that remained following the completion of the male stage were reabsorbed and did not reappear in the same floret during the subsequent female stage. The authors proposed that constituents of reabsorbed nectar that are not re-secreted in the female stage, may be utilized as a source of carbon and energy during the elongation of the style, the expansion of the stigma or to produce stigmatic secretions, as in the flowers of Streptosolen jamesonii ( $\mathrm{S} \mathrm{hue} 1$, 1961).

\section{Nectar reabsorption in pollinated and unpollinated flowers}

It is clear that in some plants, the reabsorption of nectar is evidently triggered by pollination. In African orchids such as Aerangis verdickii (Koopowitz and M a r c h a n t, 1998) and Mystacidium venosum ( $\mathrm{L} \mathrm{u} \mathrm{y} \mathrm{t} \mathrm{and} \mathrm{J} \mathrm{o} \mathrm{h} \mathrm{n} \mathrm{s} \mathrm{o} \mathrm{n} \mathrm{,} \mathrm{2002),} \mathrm{unless}$ pollination occurs, nectar is not reabsorbed rapidly. Conversely, in such European orchids as Platanthera chlorantha or Gymnadenia conopsea (S t p i c z y ń s k a, 2003 c, 2004) and in the dicot Cucurbita pepo ( $\mathrm{N}$ e p i et al., $1996 \mathrm{a}, \mathrm{b}$; 2001) nectar is quickly reabsorbed near the end of anthesis regardless of whether or not pollination has occurred. In these species, the occurrence of pollination greatly affects the rate of reabsorption and the fate of the reabsorbed sugars. Microautoradiographical studies of Platantera chlorantha and Cucurbita pepo indicate that the mobility of reabsorbed material in pollinated flowers is different from that of unpollinated flowers ( $\mathrm{S} \mathrm{t} \mathrm{p} \mathrm{i} \mathrm{-}$ czyńska 2003 b; Stpiczyńska and Nepi, 2005; Nepi and Stpiczyń$\mathrm{sk}$ a, unpublished). In the pollinated flowers of squash, where the first fertilisations occur within about 24 hours of pollination, translocation of the reabsorbed sucrose into the ovary and ovules was particularly rapid (S te ph e n s on et al., 1988; N e pi and $\mathrm{P} \mathrm{a} \mathrm{c} \mathrm{i} \mathrm{n} \mathrm{i} \mathrm{2001).} \mathrm{It} \mathrm{is,} \mathrm{therefore,} \mathrm{reasonable} \mathrm{to} \mathrm{expect} \mathrm{that} \mathrm{sucrose} \mathrm{reabsorbed} \mathrm{from}$ the nectar of male and non-pollinated, female flowers would take longer to be translocated either to adjacent flowers or to other vegetative parts of the plant. In unpollinated 
flowers of C. pepo, the ovary grows rapidly in the hours following the closing of the flower and the ovary starts to degenerate $3-4$ days later ( $\mathrm{N} \mathrm{e} \mathrm{p} \mathrm{i} \mathrm{and} \mathrm{P} \mathrm{a} \mathrm{c} \mathrm{i} \mathrm{n} \mathrm{i} \mathrm{,} \mathrm{2001).}$ Similarly, in Platanthera, microautoradiographical studies indicated that the unpollinated flowers retain only traces of reabsorbed sucrose whereas this sugar is quickly translocated to pollinated ones, regardless of their position on the inflorescence. When more than one flower in an inflorescence is pollinated, they compete with each other for materials derived from the nectar of unpollinated flowers. The ovary of the pollinated flower closest to a non-pollinated flower is invariably the main sink for reabsorbed sugars, and these become incorporated into the developing fruits. Moreover, two neighbouring pollinated flowers never share the constituents of reabsorbed nectar; rather the nectar is used within one flower (Nepi and Stpiczyńska, unpublished).

It is interesting to note that in P. chlorantha, intensive incorporation of reabsorbed sucrose occurs in the developing ovules, the placenta and storage parenchyma of the pericarp. The minute seeds of orchids usually neither develop endosperm nor contain food reserves for the developing embryo. Although the ovules of P. chlorantha at the binucleate embryo sac stage do not contain starch (unpublished results), Andronova (1998) has shown that some storage materials occur in Gymnadenia and Dactylorhiza during the early stages of embryogenesis. The absence of starch from the ovules of $P$. chlorantha and the evident presence of reabsorbed radioactive sucrose in the embryo sac and integuments may indicate that, following the hydrolysis of sucrose, the hexoses can perhaps be utilized in other metabolic pathways or incorporated into cell wall polysaccharides. In Cucurbita pepo also, the ovules, despite the absence of starch, are the sites of intensive incorporation and utilization of reabsorbed sucrose, particularly so, in the chalazal region (S t piczy ńs ka and Nepi, 2005).

\section{Transport and destination of reabsorbed sugars}

In the inflorescence of Platanthera, reabsorbed sugars can be translocated both upwards and downwards for up to $12.5 \mathrm{~cm}$ (N e p i and S t p i c z y ń s k a , unpublished). Plants are also able to reabsorb floral nectar and to utilize the sugars as well as other nectar components during the development of ovaries and seeds. Constituents of ${ }^{14} \mathrm{C}$-labelled, reabsorbed nectar are also re-used and incorporated into the stigmatic secretion of Streptosolen jamesonii ( $\mathrm{S} \mathrm{h} \mathrm{u} \mathrm{e} \mathrm{1,} \mathrm{1961).} \mathrm{However,} \mathrm{the} \mathrm{sugars} \mathrm{deri-}$ ved from reabsorbed nectar can be translocated for longer distances, e.g. to the leaves and roots, as in alfalfa (P e d e r s e n et al., 1958).

In Combretum fruticosum and Eucalyptus grandis, nectar reabsorption does not change the total sugar concentration of the nectar nor the relative proportions of the three main sugars; glucose, fructose and sucrose (B e rnarde 11 o et al., 1994; $\mathrm{D}$ a $\mathrm{v}$ is , 1997). This means that in these species, the rate of reabsorption for the three sugars is the same as that for water. On the other hand, in female flowers of Cucurbita pepo, the sugar component is reabsorbed at a greater rate than water with sucrose being selectively reabsorbed. This indicates that the transport of sucrose here is an active process whereas the reabsorption of water occurs along an osmotic gradient ( $\mathrm{N} \mathrm{e} \mathrm{p} \mathrm{i} \mathrm{et} \mathrm{al.,} 2001$ and references therein). The establishment of an osmotic gradient 
may be facilitated in that ovary, situated just below the nectary, grows rapidly in the hours following anthesis and thereby acts as an effective and substantial sink for carbohydrates.

Despite convincing evidence for the reabsorption of nectar, few detailed studies have addressed the transport and incorporation of reabsorbed sugars. One of the questions that remain to be answered is 'What is the cellular basis for nectar reabsorption by the nectary?'

According to ultrastructural studies, nectary cells during the reabsorption stage retain high metabolic activity and many of them contain dense cytoplasm and small vacuoles. Since the presence of the cell wall and high turgor pressure can limit the rate of endocytosis in plant cells, it may be that the presence of relatively small vacuoles within nectary cells may facilitate the reabsorption of nectar by endocytosis. However, microautoradiographical studies in Platanthera did not support the hypothesis that reabsorbed sucrose is transported within vesicles (S t p i c z y ń s k a, 2004). Nevertheless, the high metabolic activity characteristic of the nectary cells of $P$. chlorantha and C. pepo, together with the presence of numerous mitochondria, may indicate that the transport of sucrose is an active process. Radiolabelled tracer that was detected in the nectary cells of Platanthera during the nectar reabsorption stage occurred predominantly in the cell walls of the secretory epidermis, and, to a lesser extent, in the walls of subepidermal parenchyma cells, plastids and vacuoles ( $\mathrm{S} \mathrm{t}$ p i c z y ń s k a , 2003 a; 2004), whereas in the nectary of female flowers of Cucurbita, the radio-labelling was clearly associated with the cytoplasm of parenchyma cells. Thus, the distribution of radioactivity may indicate that reabsorbed nectar can be transported along the symplast as well as the apoplast. Sucrose, when loaded into the apoplastic space, can be taken up unchanged by sink cells or hydrolysed by an invertase to glucose and fructose that are then transported by specific carriers (L e m o i n e , 2000). Sugar-transporters contribute towards the apportioning of sugars to competing sinks and also help regulate their distribution (B u s h, 1999). An extremely important feature of this regulatory process is the linking of transporter expression to plant development. For example, B orisijuk et al. (1998) reported such sugar sensing and showed that by the controlled expression of genes and metabolism, soluble carbohydrates play an important role in coordination of plant growth and development. It has also been shown that mitotic activity is related to the concentration of glucose and, as reverse relation, to the accumulation of starch and cell expanding. In addition, Fisher and Weber (2002) reported that non-green plastids from various plant species depend to a great extent on importing hexose phosphates as a precursor for starch synthesis. Therefore, sugars reabsorbed from the nectar can be an important source of precursors for starch synthesis in various organs of the plant.

\section{Acknowledgements}

The authors are grateful to Dr Kevin L. Davies, School of Earth, Ocean and

Planetary Sciences, Cardiff University, Wales, UK for useful suggestions and for checking the English text. 


\section{REFERENCES}

A n d r o n o v a E. V., 1998. Embriogienez orchidnych. [In:] Embriologia cvietkovych rastienii II. T.B. Batygina (ed). Mir i Siemja, Sankt Petersburg, pp. 545556.

A shw orth L., Ga le t t o L., 2002. Differential nectar production between male and female flowers in wild cucurbit: Cucurbita maxima ssp. andreana (Cucurbitaceae). Can. J. Bot. 80: 12031208.

B a k e r H. G., 1975. Sugar concentrations in nectars from hummingbird flowers. Biotropica, 7: 3741.

B a ker H. G., B a ker I., 1983. Chemical constituents of nectar in relation to pollination mechanisms and phylogeny. [In:] Biochemical aspects of evolutionary biology. Nitecki M. H. (ed.). University of Chicago Press, Chicago, pp. 131171.

B ernardello G., Aguilar R., Anderson G. J., 2004. The reproductive biology of Sophora fernadeziana (Leguminosae), a vulnerable endemic species from Isla Robinson Crusoe. Amer. J. Bot. 91: 198206.

B er n a rd e 11 o L., G a l e t t o L., R o d ri g u e z I. G., 1994. Reproductive biology, variability of nectar features and pollination of Combretum fruticosum (Combretaceae) in Argentina. Bot. J. Linn. Soc. 114: 293308.

B i e le sk i R. L., Re d gw el1 R. J., 1980. Sorbitol metabolism in nectaries from flowers of Rosaceae. Austral. J. Plant Physiol. 7: 1525.

B o nni er G., 1878. Les nectaries. Am. Sci. Nat. 8: 5212.

B orisjuk L., Walenta S., Weber H., Mueller Klieser W., Wobus U., 1998. High resolution histographical mapping of glucose concentrations in developing cotyle dons of Vicia faba in relation to mitotic activity and storage processes: glucose as a possible developmental trigger. Plant J. 15: 583591.

B urqúe z A., C orbet S. A., 1991. Do flowers resorb nectar? Funct. Ecol. 5: 369379.

B u s h D. R., 1999. Sugar transporters in plant biology. Curr. Opin. Plant Biol. 2: 187191.

C o rb e t A.A., 2003. Nectar sugar content: estimating standing crop and secretion rate in the field. Apidologie, 34: 110.

Cruden R. W., Hermann S. M., Peters on S., 1983. Patterns of nectar production and plant pollinator coevolution. [In:] The biology of nectaries. B. Bentley, T. Elias (eds.), Columbia University Press, New York, pp. 80125.

$\mathrm{D}$ a $\mathrm{v}$ is A.R., 1997. Influence of floral visitation on nectar sugar composition and nectary surface changes in Eucalyptus. Apidologie, 28: 2742.

Fahn A., Rachmilewitz T., 1975. An autoradiographical study of nectar secretion in Lonicera japonica Thumb. Ann. Bot. 39: 975976.

Fis h e r K., We b e r A., 2002. Transport of carbon in non green plastids. Trends Plant Sci. 7: 345351.

He i n r i ch G., 1975. Über den glucose metabolism in nektarien zweier Aloe arten und über den mechanismus der pronektar sekretion. Protoplasma, 85: 351371.

Koopowitz H., Marchant T. A., 1998. Postpollination nectar resorption in the African epiphyte Aerangis verdickii (Orchidaceae). Amer. J. Bot. 85: 508512.

L a n ge n berger M. W., D a v is A. R., 2002. Temporal changes in floral nectar production, reabsorption, and composition associated with dichogamy in annual caraway (Carum carvi, Apiaceae). Amer. J. Bot. 89: 15881598.

L e m o in e R., 2000. Sucrose transporters in plants: update on function and structure. Biochim. Biophys. Acta, 1465: 246262. 
L u y t R., J o h n s o n S. D., 2001. Hawkmoth pollination of the African epiphytic orchid Mystacidium venosum, with special reference to flower and pollen longevity. Plant Syst. Evol. 228: 4962.

Luyt R., Johns on S. D., 2002. Postpollination nectar reabsorption and its implications for fruit quality in an epiphytic orchid. Biotropica, 34: 442446.

M a s i e r o w s k a M., S t p i c z y ń s k a M., 2005. Nectar resorption in flowers of Sinapis alba L., Brasicaceae and Platanthera chlorantha Custer (Rchb.) Orchidaceae. Proc. XVII International Botanical Congress, Vienna, Austria, p.301.

Ne p i M., C i a m p o li in i F., P a c i n i E., 1996 a. Development and ultrastructure of Cucurbita pepo nectaries of male flowers. Ann. Bot. 78: 95104.

Nepi M., Pacin i E., Wille m se M. T. M., 1996 b. Nectary biology of Cucurbita pepo: ecophysiological aspects. Acta Bot. Neerl. 45: 4154.

$\mathrm{Ne} \mathrm{p} \mathrm{i} \mathrm{M.,} \mathrm{P} \mathrm{a} \mathrm{c} \mathrm{in} \mathrm{i} \mathrm{E.,} \mathrm{2001.} \mathrm{Effect} \mathrm{of} \mathrm{pistil} \mathrm{age} \mathrm{on} \mathrm{pollen} \mathrm{tube} \mathrm{growth,} \mathrm{fruit} \mathrm{development} \mathrm{and}$ seed set in Cucurbita pepo L. Acta Soc. Bot. Pol. 70: 165172.

Nepi M., Guarnieri M., Pacini E., 2001. Nectar secretion, reabsorption, and sugar composition in male and female flowers of Cucurbita pepo. Int. J. Plant Sci. 162: 353358.

$\mathrm{N}$ i c ols o $\mathrm{n} \mathrm{S.} \mathrm{W.,} \mathrm{1995.} \mathrm{Direct} \mathrm{demonstration} \mathrm{of} \mathrm{nectar} \mathrm{resorption} \mathrm{in} \mathrm{the} \mathrm{flowers} \mathrm{of} \mathrm{Grevillea}$ robusta (Proteaceae). Funct Ecol. 9: 584588.

N i c ols o n S. W., N e p i M., 2005. Dilute nectar in dry atmospheres: nectar secretion patterns in Aloe castanea (Asphodelaceae). Int. J. Plant Sci. 166: 227233.

Pedersen M. W., Le Fevre C. W., Wi ebe H. H., 1958. Absorption of C14 labelled sucrose by alfalfa nectaries. Science, 127: 758759.

P y k e G. H., 1991. What does it cost a plant to produce nectar? Nature, 350: 5859.

Rive ir a G. L., Ga let to L., B e rn arde 11 o L., 1996. Nectar secretion pattern, removal effect, and breeding system of Ligaria cuneifolia (Loranthaceae). Can. J. Bot. 74: 1996 2001.

S a w i d is T., He in ri c h G., Ts e k o s I.,1989. Autoradiographical study of the incorporation of tritium labelled glucose (D glucose $6 \mathrm{H} 3$ ) in floral nectaries of Abutilon striatus (Dicks). Bios (Thessaloniki), 1: 211219.

S huel R. W., 1961. Influence of reproductive organs on secretion of sugars in flowers of Streptosolen jamesonii, Miers. Plant Physiol. 36: 265271.

S ou thw i ck E. E., 1984. Photosynthate allocation to floral nectar: a neglected energy invest ment. Ecology, 65: 17751779.

S t e phe n s on A. G., W in s or J. A., S c h li c h t in g C. D., 1988. Evidence for non random fertilisation in the common zucchini, Cucurbita pepo. [In:] Sexual reproduction in higher plants. M. Cresti, P. Gori., E. Pacini (eds). Springer Verlag, Berlin, pp. 333338.

S t p i z y ńs ka M., 2003 a. Nectar resorption in the spur of Platanthera chlorantha Custer (Rchb.) Orchidaceae structural and microautoradiographic study. Plant Syst. Evol. 238: 119126.

S t p i c z y ń s k a M., 2003 b. Incorporation of [3H]sucrose after the resorption of nectar from the spur of Platanthera chlorantha (Custer) Rchb. Can. J. Bot. 81: 927932.

S t p i c z y ńs k a M., 2003 c. Kwitnienie i nektarowanie gółki długoostrogowej Gymnadenia conopsea (L.). Ann. Univ. Mariae Curie Skłodowska sect. EEE Hortic. 109115.

S t p i c z y ń s k a M., 2004. Rola nektaru w kwiatach podkolanu zielonawego Platanthera chlo rantha Custer (Rchb.) Orchidaceae. Rozpr. Nauk. Akad. Roln. Lublin., Zeszyt 286. WAW, Lublin.

S t p i c z y ń s k a M., N e p i M., 2005. Nectar reabsorption and sugar translocation in male and female flowers of Cucurbita pepo. Proc. XVII International Botanical Congress, Vienna, Austria, p. 163. 
Torre s C., Ga le t to L., 1998. Patterns and implications of floral nectar secretion, chemical composition, removal effects and standing crop in Mandevilla pentlandiana Apocynace ae. Bot. J. Linn. Soc. 127: 207223.

Wit t T., Jürgens A., Ge y e r R., G ot t s berger G., 1999. Nectar dynamics and sugar composition in flowers of Silene and Saponaria species (Caryophyllaceae). Plant Biol. 1: 334345 .

\section{Ekofizjologiczne aspekty reabsorpcji nektaru}

\section{Streszczenie}

Nektar jest resorbowany w kwiatach roślin z różnych rodzin botanicznych, między innymi Apiaceae, Brassicaceae, Cucurbitaceae, Combretaceae czy Orchidaceae. Reabsorbcja nektaru spełnia kilka niezwykle ważnych funkcji i występuje niezależnie od stadium kwitnienia, płci kwiatu czy zapylenia. W kwiatach typu otwartego, reabsorpcja cukrów umożliwia regulację koncentracji, która wzrasta na skutek parowania wody z nektaru. Z kolei w kwiatach innych roślin możliwość zmiany koncentracji nektaru stanowi pewną adaptację do zapylania przez szersze spektrum gatunków, co jest niezwykle ważne w sytuacjach deficytu zapylaczy w środowisku. Inne funkcje resorpcji nektaru dotyczą energetycznego bilansu roślin. Wyniki niektórych badań wykazują, że produkcja nektaru wymaga dużego nakładu energii metabolicznej i może pochłaniać dziennie do $37 \%$ energii uzyskanej z fotosyntezy. Dlatego też niektóre rośliny odzyskują przynajmniej część energii wydatkowanej na produkcję i sekrecję nektaru poprzez reabsorpcję cukrów, jeśli nektar nie jest pobrany podczas zapylenia. Cukry te rośliny wykorzystują głównie jako materiały zapasowe w rozwijających się owocach i nasionach, które są silnymi akceptorami asymilatów. Mechanizm reabsorpcji nektaru na poziomie komórkowym wymaga dalszych szczegółowych badań. 
